Research Square
Preprints are preliminary reports that have not undergone peer review.

They should not be considered conclusive, used to inform clinical practice, or referenced by the media as validated information.

\title{
The Effect of Temperature on Physical Activity: An Aggregated Analysis of Smartphone Users in Five Major Chinese Cities
}

Janice Ying-en Ho

The Chinese University of Hong Kong

William Bernard Goggins

The Chinese University of Hong Kong

Phoenix Kit Han Mo

The Chinese University of Hong Kong

Emily Y. Y. Chan ( $\nabla$ emily.chan@cuhk.edu.hk)

Chinese University of Hong Kong https://orcid.org/0000-0002-8854-5093

\section{Research}

Keywords: temperature, physical activity, step count, China, urban

Posted Date: July 20th, 2021

DOI: https://doi.org/10.21203/rs.3.rs-698317/v1

License: (c) (i) This work is licensed under a Creative Commons Attribution 4.0 International License. Read Full License 


\section{Abstract}

\section{Background:}

Physical activity is an important factor in premature mortality reduction, non-communicable disease prevention, and well-being protection. Climate change will alter temperatures globally, with impacts already found on mortality and morbidity. While uncomfortable temperature is often perceived as a barrier to physical activity, the actual impact of temperature on physical activity has been less well studied, particularly in China. This study examined the associations between temperature and objectively measured physical activity among adult populations in five major Chinese cities.

\section{Methods:}

Aggregated anonymized step count data was obtained between December 2017-2018 for five major Chinese cities: Beijing, Shanghai, Chongqing, Shenzhen, and Hong Kong. The associations of temperature with daily aggregated mean step count were assessed using Generalized Additive Models (GAMs), adjusted for meteorological, air pollution, and time-related variables.

\section{Results:}

Significant decreases in step counts during periods of high temperatures were found for cold or temperate climate cities (Beijing, Shanghai, and Chongqing), with maximum physical activity occurring between $16-19.3^{\circ} \mathrm{C}$. High temperatures were associated with decreases of 800-1500 daily steps compared to optimal temperatures. For cities in subtropical climates (Shenzhen and Hong Kong), non-significant declines were found with high temperatures. Overall, females and the elderly demonstrated lower optimal temperatures for physical activity and larger decreases of step count in warmer temperatures.

\section{Discussion:}

As minor reductions in physical activity could consequentially affect health, an increased awareness of temperature's impact on physical activity is necessary. City-wide adaptations and physical activity interventions should seek ways to sustain physical activity levels in the face of shifting temperatures from climate change.

\section{Introduction}

The public health burden of hot and cold temperatures has been documented by studies showing impacts on excess mortality (1-5), hospital admissions (3, 6-8), as well as help-seeking behaviour (9). However, much less has been discussed about the impact of temperatures at the level of daily human activity. Physical activity is an important factor for premature mortality reduction, as insufficient physical activity is attributed to be responsible for an estimated $9 \%$ of premature deaths worldwide (10). Furthermore, physical activity plays an essential role in preventing non-communicable disease and enhancing well-being (11-13). Poor weather has often been described as a 'barrier to physical activity' in qualitative studies $(14,15)$, and research has shown that objectively-measured physical activity can be affected by temperatures $(14,16-19)$. However, few studies have been conducted in the Asia, particularly in China, although this relationship may vary across different climates and regional contexts.

With a population of 1.4 billion people as of 2019 (20), China currently has the largest population worldwide. Over the recent decades, the physical activity levels of the population have decreased, particularly in more urbanized areas (21). A study found that work- and household- physical activity decreased by nearly half between 1991 and 2011, while active leisure and transport physical activity did not see a meaningful change in the same period (22). The recent Tsinghua-Lancet Commission on healthy cities in China calls for integration of health into all policies, including the increased facilitation of physical activity (21).

With climate change, temperatures in China are predicted to increase by $2.3^{\circ} \mathrm{C}$ to $3.3^{\circ} \mathrm{C}$ from 2000 to $2050(23)$, increasing the occurrence of extremely hot temperatures in the coming decades. Yet there is a lack of understanding about the relationship between temperature and physical activity in China. Previous studies had only assessed small samples of the population (24, 25), or observed physical activity ecologically in specific locations such as public parks (26). A more comprehensive 
understanding of temperature's effect on physical activity is needed at the population level. This knowledge would support the development of policies to address these potential impacts and to promote physical activity in the cities, as called for in the Tsinghua-Lancet Commission.

Step counts are an important indicator of physical activity at the population level, as walking is a largely accessible, inexpensive, and a regularly conducted physical activity in everyday life (27). The objective measurement of step counts has enabled studies to assess day-to-day variations of physical activity and its association with temperature $(16,19,28-32)$. With the advancement of technology, this physical activity indicator has been increasingly assessed using smartphone accelerometer applications, which have been highlighted for their convenience in population studies and validated for their accuracy $(33,34)$. A systematic review found that the accuracy of smartphone physical activity measurements ranged from $73-100 \%$ regardless of phone placement ( $n=10$ studies), although lower accuracy was found for stair climbing $(52-79 \%$ accuracy) (35). Using smartphones enables utilization of the same objective physical activity measurement and study methodology across locations, facilitating multi-location comparisons (36-38).

This study examines the associations between mean temperature and daily step counts across five major Chinese cities.

\section{Methods}

\section{Study setting and design}

This is a prospective aggregated timeseries study. Five major Chinese cities were assessed including Beijing (located in the North), Shanghai (East), Chongqing (Southwest), Shenzhen (South), and Hong Kong SAR (South, Special Administrative Region). These are major cities in China, in terms of the population size, and economic and political significance. The cities are also located in four divergent areas of the country, with varying climates and topographies.

\section{Physical activity data}

Anonymous secondary data on physical activity was collected from the mobile application Wechat's in-app function WeRun (ㅁ $\mathrm{QQ}$ ) for the duration of the study period. Wechat is an app commonly used by smartphone users in China, regardless of age. The in-app function WeRun is a voluntary addition that enables users to compare fitness levels with their community and reads from the step count data of the phone's health applications (iPhone or Android) or other data sources such as smartwatches, as allowed by the user. Both the iPhone and Android phones have been validated against regularly accepted pedometers and accelerometers in field-based research $(33,39)$. These studies have found comparable estimates in both laboratory and freeliving environments, although the mobile phone-proxy estimates may be liable to underestimation due to inconstant phone carrying $(33,39)$.

The secondary physical activity data was collected from users who had specifically enabled the fitness tracking function of WeRun, authorizing the collection of their daily step counts. All data was anonymized prior to retrieval and only collected in aggregate form to protect personal privacy. Aggregated mean daily step counts were obtained for each city from anonymized users of the in-app function who were located in the city at night (10 pm). Aggregated mean daily step counts were also obtained stratified by gender and age group $(18-64,65+)$ along with the number of anonymized users included in each aggregate value.

\section{Weather and pollutant data}

Meteorological data were obtained from the China Meteorological Administration for the following stations for the mainland Chinese cities: Beijing (ID: 54511), Shanghai (ID: 58362), Chongqing (ID: 57516), and Shenzhen (ID: 59493). Data from Hong Kong was obtained from the Hong Kong Observatory. Daily mean temperature was used as the main exposure for this analysis, and also adapted into apparent temperature and percentile temperature of the study period. Apparent temperature was 
calculated from temperature and relative humidity using the following formulas, where $\mathrm{T}=$ temperature and $\mathrm{RH}=$ relative humidity $(40,41)$ :

$$
\begin{gathered}
H=(\log 10(R H)-2) / 0.4343+\left(17.62 * T_{\text {air }}\right) /\left(243.12+T_{\text {air }}\right) \\
T_{\text {dewpt }}=243.12 * H /(17.62-H) \\
T_{\text {apparent }}=-2.653+0.994\left(T_{\text {air }}\right)+0.0153\left(T_{\text {dewpt }}\right)^{2}
\end{gathered}
$$

Other daily meteorological covariates obtained from the meteorological stations included: mean relative humidity, total rainfall, mean wind speed, mean atmospheric pressure, and total sunshine hours. A square root transformation was done for rainfall and windspeed, in order to reduce the effect of outliers. Extreme weather event information on typhoon days were incorporated as binary indicators from a WMO report on China and the Hong Kong Observatory (42-44). The occurrence of super typhoon Mangkhut was included separately due to the severity of the storm, which made landfall in Shenzhen and Hong Kong on Sept $16,2018$.

Air pollution data was obtained from China National Environmental Monitoring Center network (CNEMC) and Hong Kong Environmental Protection Department. An air quality index was used instead of individual air pollutant variables, to reduce possible collinearity. In China, the Air Quality Index (AQI) is based on the concentration levels of six pollutants (SO2, NO2, PM2.5, PM10, CO, 03) and reported using a scale of 1-300+ (45). All hourly AQI values were aggregated to the daily level and further log-transformed to adjust for the right skew. Missing variables were imputed using a simple moving average for consecutively missing data of twelve hours or less. Longer consecutive missing data were left as missing. The imputation was completed with the R package 'imputeTS'. In Hong Kong, the Air Quality Health Index (AQHI) was used, based on the concentration levels of four pollutants ( $\mathrm{SO} 2, \mathrm{NO} 2, \mathrm{O} 3$, and particulate matter) and reported using a scale of 1-10+ (46). Hourly $\mathrm{AQHI}$ values were available for twelve general stations located throughout the city, which were averaged together to indicate the daily value for the entire city. For values ' $10+$ ', a value of 12 was used in the daily aggregation. The Tap Mun monitoring station was not included, as its rural location is not reflective of the residence of the general population.

Time-related variables, such as month, day of week (DOW), and public holiday, were included to control the analysis. Mainland China had extra workdays to compensate for extended holiday periods, which were adjusted for in the analysis as well (47). A city-wide marathon was included as a special event in Hong Kong during the study period and adjusted for in the analysis (48). The authors were unable to identify the occurrence of city-wide events in the other Chinese cities during the study period.

\section{Statistical analysis}

The associations of temperature were assessed on aggregated mean daily step count, adjusted by other meteorological conditions, air pollution index, and time-related variables. A stepdown analysis was conducted separately for each city using Generalized Additive Models (GAMs). Meteorological covariates with the highest p-value were removed in each model, until no variables with p-value over 0.1 remained. The AIC was also compared between models to ensure the model quality did not decrease. Air pollution index and time-related variables were kept in the model as control variables. The full model had a formula as follows: 


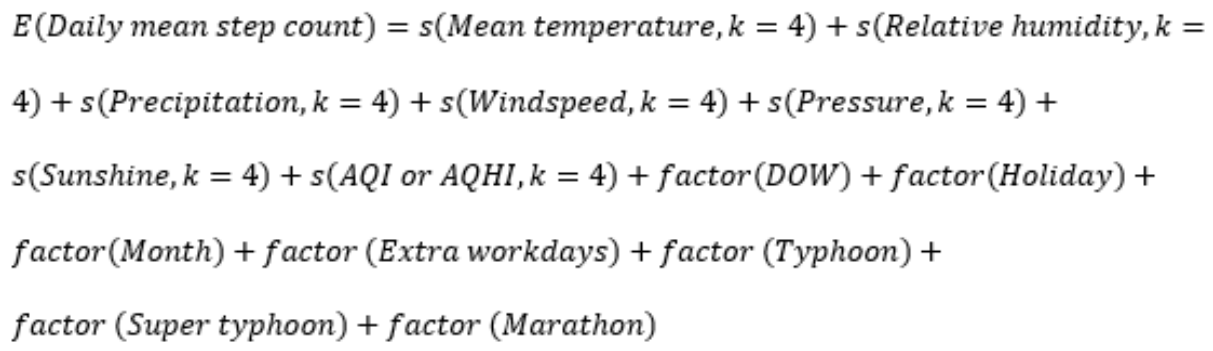

$\mathrm{s}()$ indicates the smoothing function of continuous independent variables in R package "mgcv"

$\mathrm{k}$ indicates the basis dimension for the smooth, such that $\mathrm{k}-1$ is the maximum degrees of freedom considered for the variable factor() indicates the categorical independent variables; variables were excluded if irrelevant to the city

The analysis was further stratified by gender and age group. Sensitivity analyses assessed the 1) effect of apparent temperature, 2) effect of percentile temperature, 3) removal of air pollution index, and 4) removal of outlier data caused by Typhoon Mangkhut in Shenzhen and Hong Kong. Statistical significance level was set at $p \leq 0.05$. All analyses were conducted using R version 3.5.2 (49), using the package "mgcv" (gam) (50).

\section{Results}

\section{Descriptive statistics}

The study period was from $\operatorname{Dec} 6,2017$ to Dec 31, 2018. The average amount of anonymized users included during the study period were 11.1 million for Beijing, 9.6 mil for Shanghai, 2.8 mil for Chongqing, 4.9 mil for Shenzhen and 0.4 mil for Hong Kong. Compared to census data, the study samples in all five cities had a comparable gender distribution with their respective general populations (see Table 1). However, the sample populations tended to be significantly younger than the general population.

Table 2 displays the summary findings. The aggregated average step counts for each of the cities during the study period averaged 6846 steps for Beijing, 6703 for Shanghai, 7540 for Chongqing, 7209 for Shenzhen and 9040 for Hong Kong. The average step count was significantly higher among males than females (T-test, $p<0.001$ ). During the study period, daily temperatures averaged from $12.7^{\circ} \mathrm{C}\left( \pm\right.$ SD 12.1) in Beijing, to $23.5^{\circ} \mathrm{C}( \pm$ SD 5.3) in Hong Kong.

Table 1 Demographic comparison between sample population and city population of five Chinese cities (Unit 10,000 persons) 


\begin{tabular}{|c|c|c|c|c|c|c|}
\hline \multirow[t]{2}{*}{ City } & \multicolumn{3}{|l|}{ Sample } & \multicolumn{2}{|c|}{ Population (2018) } & \multirow[t]{2}{*}{ p-value } \\
\hline & Category & Sample size (\%) & $\pm S D$ & Category & $N(\%)$ & \\
\hline \multirow[t]{7}{*}{ Beijing } & Total & $1108.9(100.0)$ & 167.3 & Total & $2154.2(100.0)$ & \\
\hline & \multicolumn{6}{|l|}{ Gender } \\
\hline & Male & $555.2(50.1)$ & 81.7 & Male & $1095.6(50.9)$ & 0.879 \\
\hline & Female & $553.7(49.9)$ & 85.7 & Female & $1058.6(49.1)$ & \\
\hline & Age & & & Total 15+ & 1927.6 & \\
\hline & $18-64$ & $1095.2(98.8)$ & 163.4 & $15-64$ & $1686.2(87.5)$ & $<0.001^{*}$ \\
\hline & $65+$ & $13.7(1.2)$ & 4.0 & $65+$ & $241.4(12.5)$ & \\
\hline \multirow[t]{7}{*}{ Shanghai } & Total & $963.5(100.0)$ & 137.3 & Total & $1462.4(100.0)$ & \\
\hline & \multicolumn{6}{|l|}{ Gender } \\
\hline & Male & $462.5(48.0)$ & 63.9 & Male & $724.1(49.5)$ & 0.761 \\
\hline & Female & $501.0(52.0)$ & 73.4 & Female & $738.2(50.5)$ & \\
\hline & Age & & & Total 18+ & 1285.9 & \\
\hline & $18-64$ & $947.2(98.3)$ & 132.3 & $18-59$ & $783.9(61.0)$ & $<0.001^{*}$ \\
\hline & $65+$ & $16.3(1.7)$ & 5.1 & $60+$ & $502.0(39.0)$ & \\
\hline \multirow[t]{7}{*}{ Chongqing } & Total & $286.0(100.0)$ & 46.1 & Total & $3101.8(100.0)$ & \\
\hline & \multicolumn{6}{|l|}{ Gender } \\
\hline & Male & $131.4(45.9)$ & 21.1 & Male & $1563.4(50.4)$ & 0.368 \\
\hline & Female & $154.6(54.1)$ & 25.1 & Female & $1538.4(49.6)$ & \\
\hline & Age & & & Total 15+ & 2572.3 & \\
\hline & $18-64$ & $282.3(98.7)$ & 44.9 & $15-64$ & 2135.0 (83.0) & $<0.001^{*}$ \\
\hline & $65+$ & $3.6(1.3)$ & 1.2 & $65+$ & $437.4(17.0)$ & \\
\hline \multirow[t]{7}{*}{ Shenzhen } & Total & $489.8(100.0)$ & 66.6 & Total & $1302.7(100.0)$ & \\
\hline & \multicolumn{6}{|l|}{ Gender } \\
\hline & Male & $269.3(55.0)$ & 37.8 & Male & 707.8 (54.3) & 0.893 \\
\hline & Female & $220.5(45.0)$ & 28.9 & Female & $594.9(45.7)$ & \\
\hline & Age & & & Total $18+$ & 1 & \\
\hline & $18-64$ & $487.4(99.5)$ & 66.2 & $18-64$ & 1 & NA \\
\hline & $65+$ & $2.4(0.5)$ & 0.5 & $65+$ & 1 & \\
\hline Hong Kong & Total & $42.8(100.0)$ & 6.7 & Total & $7486.4(100.0)$ & \\
\hline
\end{tabular}




\begin{tabular}{llllll} 
Gender & & & & & \\
Male & $18.6(43.5)$ & 2.9 & Male & $3421.1(45.7)$ & 0.659 \\
\hline Female & $24.2(56.5)$ & 3.8 & Female & $4065.3(54.3)$ & \\
\hline Age & & & Total 15+ & 6620.2 & \\
\hline $18-64$ & $42.5(99.3)$ & 6.6 & $15-64$ & $5318.6(80.3)$ & $<0.001$ * \\
\hline $65+$ & $0.3(0.7)$ & 0.1 & $65+$ & $1301.6(19.7)$ &
\end{tabular}

Note: Chi-square test was used to measure the overall difference in proportion between the sample and 2018 population data. Population age group categories were based on the available census data per city; no age group data was found for Shenzhen. Census data sources: $(63-67)$

$\backslash$ indicates the absence of data.

* $p \leq 0.05$ indicates significant difference.

Table 2 Summary findings of five Chinese cities 


\begin{tabular}{|c|c|c|c|c|c|c|}
\hline Variables & Beijing (BJ) & $\begin{array}{l}\text { Shanghai } \\
\text { (SH) }\end{array}$ & $\begin{array}{l}\text { Chongqing } \\
\text { (CQ) }\end{array}$ & $\begin{array}{l}\text { Shenzhen } \\
\text { (SZ) }\end{array}$ & $\begin{array}{l}\text { Hong Kong } \\
(\mathrm{HK})\end{array}$ & p-value \\
\hline Observation days & 391 & 391 & 391 & 391 & 391 & \\
\hline \multicolumn{7}{|l|}{ Physical activity } \\
\hline $\begin{array}{l}\text { Total avg. daily step count, } \\
\text { mean }( \pm S D)\end{array}$ & $\begin{array}{l}6846.0 \\
(478.4)\end{array}$ & $\begin{array}{l}6702.5 \\
(463.3)\end{array}$ & $\begin{array}{l}7540.1 \\
(507.6)\end{array}$ & $\begin{array}{l}7209.4 \\
(402.7)\end{array}$ & $\begin{array}{l}9039.6 \\
(429.1)\end{array}$ & $<0.001^{\star}$ \\
\hline Males, mean $( \pm S D)$ & $\begin{array}{l}7594.3 \\
(518.2)\end{array}$ & $\begin{array}{l}7465.3 \\
(500.9)\end{array}$ & $\begin{array}{l}8079.8 \\
(461.9)\end{array}$ & $\begin{array}{l}7862.8 \\
(415.2)\end{array}$ & $\begin{array}{l}9635.2 \\
(430.4)\end{array}$ & $<0.001^{\star}$ \\
\hline Females, mean $( \pm S D)$ & $\begin{array}{l}6095.1 \\
(454.1)\end{array}$ & $\begin{array}{l}5998.1 \\
(444.3)\end{array}$ & $\begin{array}{l}7081.4 \\
(561.2)\end{array}$ & $\begin{array}{l}6412.1 \\
(416.4)\end{array}$ & $\begin{array}{l}8580.1 \\
(443.4)\end{array}$ & $<0.001$ * \\
\hline Age group 18-64, mean $( \pm S D)$ & $\begin{array}{l}6850.0 \\
(477.6)\end{array}$ & $\begin{array}{l}6707.7 \\
(461.2)\end{array}$ & $\begin{array}{l}7535.6 \\
(505.7)\end{array}$ & $\begin{array}{l}7208.0 \\
(401.8)\end{array}$ & $\begin{array}{l}9047.7 \\
(429.2)\end{array}$ & $<0.001^{\star}$ \\
\hline Age group $65+$, mean $( \pm S D)$ & $\begin{array}{l}6505.9 \\
(614.4)\end{array}$ & $\begin{array}{l}6385.3 \\
(648.2)\end{array}$ & $\begin{array}{l}7899.5 \\
(708.8)\end{array}$ & $\begin{array}{l}7485.1 \\
(620.6)\end{array}$ & $\begin{array}{l}7966.0 \\
(461.9)\end{array}$ & $<0.001^{*}$ \\
\hline \multicolumn{7}{|l|}{ Meteorological } \\
\hline Station ID & 54511 & 58362 & 57516 & 59493 & HKO & \\
\hline $\begin{array}{l}\text { Climate (Köppen-Geiger } \\
\text { classification) }\end{array}$ & Dwa & $\mathrm{Cfa}$ & $\mathrm{Cfa}$ & Cwa & Cwa & \\
\hline Temperature, range & -9.2 to 32.5 & -1.0 to 32.6 & 4.5 to 36.5 & 6.6 to 30.8 & 9.0 to 31.2 & \\
\hline Temp, ${ }^{\circ} \mathrm{C}$ mean $( \pm S D)$ & $12.7(12.1)$ & $17.0(9.3)$ & $18.7(8.4)$ & $23.0(5.5)$ & $23.5(5.3)$ & $<0.001^{*}$ \\
\hline Apparent temp, ${ }^{\circ} \mathrm{C}$ mean $( \pm S D)$ & $13.5(12.6)$ & $18.0(12.5)$ & $19.6(11.1)$ & $26.0(8.7)$ & $26.8(8.3)$ & $<0.001^{*}$ \\
\hline Relative humidity, mean ( $\pm S D$ ) & $48.0(19.2)$ & $73.4(12.6)$ & $75.23(12.0)$ & $74.7(14.0)$ & $76.2(10.8)$ & $<0.001^{*}$ \\
\hline Rainfall days, non-zero (\%) & $58(14.8)$ & $140(35.8)$ & $173(44.2)$ & $122(31.4)$ & $226(57.8)$ & $<0.001^{\star}$ \\
\hline Rainfall, mean $( \pm S D)$ & $1.4(7.3)$ & $3.7(11.3)$ & $3.1(8.0)$ & $5.0(15.3)$ & $5.5(16.0)$ & $<0.001^{*}$ \\
\hline Windspeed, m/s ( $\pm S D)$ & $2.0(0.8)$ & $2.6(1.0)$ & $1.3(0.4)$ & $1.9(0.7)$ & $6.6(3.0)$ & $<0.001^{*}$ \\
\hline Pressure, mean $( \pm S D)$ & $\begin{array}{l}1013.9 \\
(10.6)\end{array}$ & $1016.8(9.5)$ & $983.6(9.2)$ & $1005.7(7.0)$ & $1013.1(7.0)$ & $<0.001^{\star}$ \\
\hline Sunshine, mean $( \pm S D)$ & $6.8(3.7)$ & $5.1(4.2)$ & $3.1(4.1)$ & $5.3(3.8)$ & $5.3(3.9)$ & $<0.001^{\star}$ \\
\hline \multicolumn{7}{|l|}{ Precision variables } \\
\hline AQI, mean $( \pm S D)$ & $82.7(48.7)$ & $64.9(32.7)$ & $65.1(31.5)$ & $48.3(17.0)$ & 1 & $<0.001^{\star}$ \\
\hline $\mathrm{AQHI}$, mean $( \pm S D)$ & 1 & 1 & 1 & 1 & $3.5(1.1)$ & NA \\
\hline Holiday (\%) & $25(6.4)$ & $25(6.4)$ & $25(6.4)$ & $25(6.4)$ & $19(4.9)$ & 0.863 \\
\hline Extra workdays (\%) & $7(1.8)$ & $7(1.8)$ & $7(1.8)$ & $7(1.8)$ & $0(0.0)$ & NA \\
\hline Typhoon (\%) & $0(0.0)$ & $5(1.3)$ & $0(0.0)$ & $2(0.5)$ & $9(2.3)$ & $0.001 *$ \\
\hline Super typhoon (\%) & $0(0.0)$ & $0(0.0)$ & $0(0.0)$ & $1(0.3)$ & $1(0.3)$ & 0.557 \\
\hline Marathon (\%) & $0(0.0)$ & $0(0.0)$ & $0(0.0)$ & $0(0.0)$ & $1(0.3)$ & NA \\
\hline
\end{tabular}

Note: Chi-square test was used to measure the overall difference in proportion between the cities.

$\backslash$ indicates the absence of data. 
* $p \leq 0.05$ indicates significant difference.

\section{Main model}

The final models for Beijing, Chongqing, and Hong Kong underwent a stepdown process, in which atmospheric pressure and relative humidity were removed (see Table 3). For Shanghai and Shenzhen, no changes were required from the full models.

Table 3 Stepdown models of five Chinese cities

\begin{tabular}{|llllll|}
\hline & Beijing (BJ) & Shanghai (SH) & Chongqing (CQ) & Shenzhen (SZ) & Hong Kong (HK) \\
\hline Full model & AlC (df) & AIC (df) & AIC (df) & AIC (df) & AIC (df) \\
\hline Stepdown 1 & $4833.6(34.0)$ & $4851.0(38.6)$ & $4930.0(39.7)$ & $4795.1(38.9)$ & $5369.0(32.6)$ \\
\hline Stepdown 2 & Process stopped & $\begin{array}{l}\text { Process } \\
\text { stopped }\end{array}$ & $4931.6(38.2)$ & $\begin{array}{l}\text { Process } \\
\text { stopped }\end{array}$ & $5367.1(31.6)$ \\
\hline $\begin{array}{l}\text { Variables } \\
\text { removed }\end{array}$ & $\begin{array}{l}\text { Removed } \\
\text { pressure }\end{array}$ & Process stopped & $\begin{array}{l}\text { Removed } \\
\text { pressure }\end{array}$ & & $5365.2(30.6)$ \\
\hline
\end{tabular}

Note: $\mathrm{AIC}=$ Akaike information criterion; $\mathrm{df}=$ degrees of freedom

Overall, three of five cities (Beijing, Shanghai, and Chongqing) had significant inverse U-shaped associations between temperature and daily step count in high temperatures (see Table 4 and Figure 1). During periods of high temperature, populations in Beijing, Shanghai, and Chongqing had significantly lower physical activity compared to optimal temperatures, while no significant associations were found in Shenzhen and Hong Kong. In periods of low temperatures, while populations in Beijing, Shanghai, and Shenzhen also found significantly lower step counts compared to optimal temperatures, the amount of decrease was less than in hot temperatures. The optimal temperature of peak step counts varied slightly between cities. In Beijing, the estimate of optimal temperature was at $19.3^{\circ} \mathrm{C}$, with a change in -386.0 steps $(95 \% \mathrm{Cl}:-626.6,-145.5)$ for a $10^{\circ} \mathrm{C}$ increase from optimal temperature. In Shanghai, the optimal temperature was $17.9^{\circ} \mathrm{C}$, with a change in $-432.7 \mathrm{steps}(95 \% \mathrm{Cl}$ : $-636.2,-229.1)$ and in Chongqing, the optimal temperature was $16.1^{\circ} \mathrm{C}$, with a -321.7 decrease $(95 \% \mathrm{Cl}:-526.6,-116.8)$ in average step count for $10^{\circ} \mathrm{C}$ increase from optimal temperature. On days with extremely hot temperatures, step counts decreased, by -820 steps at $32.6^{\circ} \mathrm{C}$ in Shanghai, and -1494 steps at $36.5^{\circ} \mathrm{C}$ in Chongqing when compared to their respective optimal temperatures.

In Shenzhen, a curvilinear association was found albeit non-significant at higher temperatures. At the highest temperature in the dataset $\left(30.8^{\circ} \mathrm{C}\right)$, there was a non-significant decrease of -204.8 step counts $(95 \% \mathrm{Cl}:-514.5,104.8)$ compared to the optimal temperature $\left(24.2^{\circ} \mathrm{C}\right)$. On the other hand, a weak non-significant negative linear temperature association was found for Hong Kong (Change in steps at $10^{\circ} \mathrm{C}$ from pre-set temperature $20^{\circ} \mathrm{C}:-105.4 ; 95 \% \mathrm{Cl}-268.5,57.6$ ).

For other meteorological variables, higher relative humidity was negatively associated with step counts in Shanghai, Chongqing, and Shenzhen in a non-linear manner (see Figure S1). High relative humidity in Beijing had a non-significant association with average step count. Rainfall and windspeeds were negatively associated with daily step count in all five cities, while daily sunshine hours were positively associated with step count, with a particularly strong association observed in inland Chongqing. Where atmospheric pressure remained in the model, it was found to be positively associated with step counts in Shenzhen and Shanghai. The air pollution index was significantly associated with physical activity levels in all cities except Beijing. Overall, the final model of these cities explained $73 \%$ to $88 \%$ of the variance in daily mean step counts (see Table 4 for model information).

Table 4 Mean temperature associations on daily average step count, by city 


\begin{tabular}{|c|c|c|c|c|c|}
\hline City & Beijing & Shanghai & Chongqing & Shenzhen & Hong Kong \\
\hline Optimal temperature & 19.3 & 17.9 & 16.1 & 24.2 & $20^{a}$ \\
\hline \multirow{2}{*}{$\begin{array}{l}\text { Change in steps at OptT - 10C (95\% } \\
\mathrm{Cl})\end{array}$} & -342.8 * & -251.6 * & -19.1 & $-351.7 *$ & -3.0 \\
\hline & $\begin{array}{l}(-452.2 \\
-233.4)\end{array}$ & $(-423.0,-80.1)$ & $\begin{array}{l}(-293.1 \\
254.9)\end{array}$ & $\begin{array}{l}(-614.8 \\
-88.6)\end{array}$ & $\begin{array}{l}(-331.8 \\
325.8)\end{array}$ \\
\hline \multirow{2}{*}{$\begin{array}{l}\text { Change in steps at OptT + 10C (95\% } \\
\mathrm{Cl})\end{array}$} & $-386.0 *$ & $-432.7 *$ & $-321.7 *$ & $-204.8^{b}$ & -105.4 \\
\hline & $\begin{array}{l}(-626.6 \\
-145.5)\end{array}$ & $\begin{array}{l}(-636.2 \\
-229.1)\end{array}$ & $\begin{array}{l}(-526.6 \\
-116.8)\end{array}$ & $\begin{array}{l}(-514.5 \\
104.8)\end{array}$ & $(-268.5,57.6)$ \\
\hline $\mathrm{N}$ & 366 & 366 & 366 & 361 & 391 \\
\hline Adjusted R squared & 0.88 & 0.86 & 0.86 & 0.80 & 0.73 \\
\hline AIC & 4828.1 & 4856.0 & 4931.6 & 4795.1 & 5365.2 \\
\hline
\end{tabular}

Note: $\mathrm{BJ}=$ Beijing, $\mathrm{SH}=$ Shanghai, $\mathrm{CQ}=$ Chongqing, $\mathrm{SZ}$ = Shenzhen, $\mathrm{HK}=$ Hong Kong; OptT = optimal temperature; $\mathrm{Cl}=$ confidence interval; $\mathrm{AIC}=$ Akaike information criterion. The model for each city was adjusted for relative humidity\#, precipitation, windspeed, pressure\#, sunshine, AQI/AQHI, month, day of week, public holiday, extra workdays, typhoon, super typhoon, and marathon (\#some cities had these variables removed in the stepdown process).

aWhere association was not curvilinear, the optimal temperature was pre-set to $20^{\circ} \mathrm{C}$

${ }^{\mathrm{b}} \mathrm{A}$ change from $30.8^{\circ} \mathrm{C}$ was used for Shenzhen, since this was the upper limit of temperature data in the city.

* $p \leq 0.05$ indicates significant difference.

\section{Stratified analyses}

When stratified by gender, a lower optimal temperature was found among females than males in all four cities with curvilinear associations (Beijing, Shanghai, Chongqing, and Shenzhen) (see Table 5). A slightly larger decline in step counts was found in Beijing among females at $10^{\circ} \mathrm{C}$ above the optimal temperature $\left(28.7^{\circ} \mathrm{C}\right.$, change in steps: $\left.-405.4 ; 95 \% \mathrm{Cl}:-641.1,-169.6\right)$.

Alternately, in Shenzhen a slightly larger effect was found among females at $10^{\circ} \mathrm{C}$ colder temperatures from optimal $\left(13.5^{\circ} \mathrm{C}\right.$, change in steps: $-338.1 ; 95 \% \mathrm{Cl}:-629.9,-46.4)$. In Hong Kong, the associations among both males and females remained nonsignificant.

When stratified by age group, a lower optimal temperature was also found for the elderly over 65 in all cities with curvilinear associations (Beijing, Shanghai, Shenzhen, Hong Kong). In Chongqing, the association among the elderly was no longer inverse U-shaped, but had a steep significant negative slope. Additionally, in warmer temperatures, the elderly were associated with a markedly larger decrease in step counts compared with the adult age group (aged 18-64), with an approximate additional reduction of $\sim 70$ steps in Beijing and Shanghai and $~ 1200$ steps in Chongqing. Furthermore, in Shenzhen and Hong Kong, the association of decreased step counts in warm temperatures was found significant among the elderly, while still remaining nonsignificant among the adults. In cold temperatures, there was no clear difference between the elderly and adults in most cities, except in Shenzhen, where the elderly were associated with a larger decrease in step counts with an approximate additional $130 \sim$ steps.

Table 5. Stratification results of the temperature-physical activity associations in five Chinese cities 


\begin{tabular}{|c|c|c|c|c|c|c|c|c|c|c|}
\hline City & $\begin{array}{l}\text { Stratifi- } \\
\text { cation }\end{array}$ & OptTa & $\begin{array}{l}\text { OptT - } \\
\text { 10C }\end{array}$ & $\begin{array}{l}\text { Change in } \\
\text { steps }\end{array}$ & $95 \% \mathrm{Cl}$ & Sig. & $\begin{array}{l}\text { OptT } \\
+ \\
10 \mathrm{C}\end{array}$ & $\begin{array}{l}\text { Change in } \\
\text { steps }\end{array}$ & $95 \% \mathrm{Cl}$ & Sig. \\
\hline \multirow[t]{4}{*}{ BJ } & Male & 20.0 & 10.0 & -344.9 & $\begin{array}{l}-453.2 \\
-236.6\end{array}$ & * & 29.9 & -353.4 & $\begin{array}{l}-614.0 \\
-92.7\end{array}$ & * \\
\hline & Female & 18.7 & 8.7 & -339.2 & $\begin{array}{l}-456.4 \\
-222.0\end{array}$ & * & 28.7 & -405.4 & $\begin{array}{l}-641.1 \\
-169.6\end{array}$ & * \\
\hline & $18-64$ & 19.3 & 9.3 & -344.1 & $\begin{array}{l}-453.0 \\
-235.2\end{array}$ & * & 29.3 & -383.8 & $\begin{array}{l}-624.1 \\
-143.5\end{array}$ & * \\
\hline & $65+$ & 16.5 & 6.5 & -314.9 & $\begin{array}{l}-517.0 \\
-112.8\end{array}$ & * & 26.5 & -466.4 & $\begin{array}{l}-762.7 \\
-170.1\end{array}$ & * \\
\hline \multirow[t]{4}{*}{$\mathrm{SH}$} & Male & 18.6 & 8.6 & -249.6 & $\begin{array}{l}-422.6 \\
-76.5\end{array}$ & * & 28.6 & -427.4 & $\begin{array}{l}-656.2 \\
-198.7\end{array}$ & * \\
\hline & Female & 17.3 & 7.3 & -250.6 & $\begin{array}{l}-427.5 \\
-73.7\end{array}$ & * & 27.3 & -418.7 & $\begin{array}{l}-609.1 \\
-228.4\end{array}$ & * \\
\hline & $18-64$ & 18.0 & 8.0 & -251.9 & $\begin{array}{l}-422.1 \\
-81.8\end{array}$ & * & 28.0 & -430.1 & $\begin{array}{l}-635.1 \\
-225.1\end{array}$ & * \\
\hline & $65+$ & 13.5 & 3.5 & -318.6 & $\begin{array}{l}-657.2 \\
20.1\end{array}$ & & 23.5 & -501.3 & $\begin{array}{l}-708.4 \\
-294.2\end{array}$ & * \\
\hline \multirow[t]{4}{*}{ CQ } & Male & 18.0 & 8.0 & 16.1 & $\begin{array}{l}-200.4 \\
232.6\end{array}$ & & 28.0 & -336.2 & $\begin{array}{l}-551.6 \\
-120.9\end{array}$ & * \\
\hline & Female & 15.6 & 5.6 & -76.6 & $\begin{array}{l}-383.3 \\
230.1\end{array}$ & & 25.6 & -376.7 & $\begin{array}{l}-589.0 \\
-164.5\end{array}$ & * \\
\hline & $18-64$ & 16.2 & 6.2 & -20.4 & $\begin{array}{l}-289.2 \\
248.4\end{array}$ & & 26.2 & -327.2 & $\begin{array}{l}-533.0 \\
-121.4\end{array}$ & * \\
\hline & $65+$ & $20^{a}$ & 10.0 & -2.4 & $\begin{array}{l}-292.9 \\
288.2\end{array}$ & & 30.0 & -1541.8 & $\begin{array}{l}-1927.0 \\
-1156.7\end{array}$ & * \\
\hline \multirow[t]{4}{*}{ SZ } & Male & 24.3 & 14.3 & -291.8 & $\begin{array}{l}-536.9 \\
-46.6\end{array}$ & * & $30.8^{b}$ & -185.8 & $\begin{array}{l}-486.0 \\
114.5\end{array}$ & \\
\hline & Female & 23.5 & 13.5 & -338.1 & $\begin{array}{l}-629.9 \\
-46.4\end{array}$ & * & $30.8^{b}$ & -242.2 & $-571.0,86.5$ & \\
\hline & $18-64$ & 24.2 & 14.2 & -350.8 & $\begin{array}{l}-613.5 \\
-88.0\end{array}$ & * & $30.8^{b}$ & -203.5 & $\begin{array}{l}-513.1 \\
106.0\end{array}$ & \\
\hline & $65+$ & 22.5 & 12.5 & -487.5 & $\begin{array}{l}-903.1 \\
-71.9\end{array}$ & * & $30.8^{b}$ & -462.4 & $\begin{array}{l}-901.8 \\
-23.0\end{array}$ & * \\
\hline \multirow[t]{4}{*}{ HK } & Male & $20^{a}$ & 10.0 & -4.5 & $\begin{array}{l}-312.7 \\
303.7\end{array}$ & & 30.0 & -128.9 & $-281.8,24.1$ & \\
\hline & Female & $20^{\mathrm{a}}$ & 10.0 & -3.4 & $\begin{array}{l}-358.4 \\
351.6\end{array}$ & & 30.0 & -96.7 & $-272.9,79.5$ & \\
\hline & $18-64$ & $20^{\mathrm{a}}$ & 10.0 & -3.6 & $\begin{array}{l}-333.1 \\
325.8\end{array}$ & & 30.0 & -104.0 & $-267.5,59.5$ & \\
\hline & $65+$ & 17.1 & $9.0^{b}$ & -41.6 & $\begin{array}{l}-348.9 \\
265.7\end{array}$ & & 27.1 & -193.2 & $\begin{array}{l}-290.1 \\
-96.4\end{array}$ & * \\
\hline
\end{tabular}

Note: $\mathrm{BJ}=$ Beijing, $\mathrm{SH}=$ Shanghai, $\mathrm{CQ}=$ Chongqing, $\mathrm{SZ}$ = Shenzhen, $\mathrm{HK}=$ Hong Kong; OptT = optimal temperature; $\mathrm{Cl}=$ confidence interval. The model for each city was adjusted for relative humidity\#, precipitation, windspeed, pressure\#, sunshine, 
AQI/AQHI, month, day of week, public holiday, extra workdays, typhoon, super typhoon, and marathon (\#some cities had these variables removed in the stepdown process).

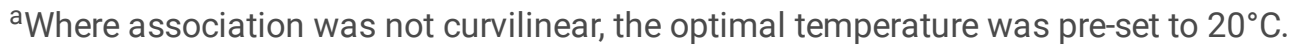

${ }^{\text {b}}$ The upper or lower limit of temperature was reached for that city's dataset. The upper limit of temperature in the Shenzhen dataset was at $30.8^{\circ} \mathrm{C}$. The lower limit of temperature in Hong Kong was at $9.0^{\circ} \mathrm{C}$.

* $p \leq 0.05$ indicates significant difference.

\section{Sensitivity analyses}

Several sensitivity analyses were conducted including 1) examining the effect of apparent temperature and 2) examining the effect of percentile temperature, 3) removal of air pollution index, and 4) removal of outlier data caused by Typhoon Mangkhut in Shenzhen and Hong Kong on Sept 16, 2018. The results were largely consistent with the primary findings (see Table 6).

For apparent temperature models, the AIC was higher than for the original models in all cities aside from Hong Kong. A slightly higher optimal apparent temperature was found in Beijing, Shanghai, and Shenzhen. A slightly lower optimal apparent temperature was found in Chongqing, although the effect at $+10^{\circ} \mathrm{C}$ was no longer significant. In Hong Kong, the effect at $+10^{\circ} \mathrm{C}$ from $20^{\circ} \mathrm{C}$ was to significantly decrease step counts by -83.7 (95\% $\left.\mathrm{Cl}:-150.4,-17.1\right)$.

Optimal percentile temperature was found at the $48^{\text {th }}$ percentile in Chongqing, $54^{\text {th }}$ percentile in Shanghai, $58^{\text {th }}$ percentile in Shenzhen, and $68^{\text {th }}$ percentile in Beijing. Similar to the main model, no optimal percentile temperature was found for Hong Kong. The model AIC improved when using percentile temperature for all cities except Chongqing.

Without the pollution index, the results remained consistent in Beijing, Shanghai, and Shenzhen, although the model AIC had a substantial increase from each city's original model. In Chongqing, the optimal temperature increased from $16^{\circ} \mathrm{C}$ to $19.3^{\circ} \mathrm{C}$. Additionally, a curvilinear association was found in Hong Kong, with optimal temperatures at $21.9^{\circ} \mathrm{C}$ and a marginally significant decrease of $-348.0(95 \% \mathrm{Cl}:-697.8,1.8)$ for a $10^{\circ} \mathrm{C}$ increase from optimal temperature.

The results remained consistent when removing the typhoon outlier for Shenzhen and Hong Kong, while the model AIC improved from the original. When the two cities were hit by Typhoon Mangkhut on Sept 16, 2018, the aggregated daily step counts on that date dropped significantly to 3992 and 4682, respectively compared to average step counts.

Table 6. Sensitivity analyses of the temperature-physical activity associations in five Chinese cities 


\begin{tabular}{|c|c|c|c|c|c|c|c|c|c|c|c|c|}
\hline City & Model & OptTa & $\begin{array}{l}\text { OptT } \\
-10 \mathrm{C}\end{array}$ & $\begin{array}{l}\text { Change } \\
\text { in } \\
\text { steps }\end{array}$ & $\begin{array}{l}95 \% \\
\mathrm{Cl}\end{array}$ & Sig. & $\begin{array}{l}\text { OptT } \\
+ \\
{ }_{10 \mathrm{C}}\end{array}$ & $\begin{array}{l}\text { Change } \\
\text { in } \\
\text { steps }\end{array}$ & $95 \% \mathrm{Cl}$ & Sig. & df & AIC \\
\hline \multirow[t]{4}{*}{ BJ } & $\begin{array}{l}\text { Original } \\
\text { (Mean } \\
\text { Temp) }\end{array}$ & 19.3 & 9.3 & -342.8 & $\begin{array}{l}-452.2 \\
-233.4\end{array}$ & * & 29.3 & -386.0 & $\begin{array}{l}-626.6 \\
-145.5\end{array}$ & * & 33.8 & 4828.1 \\
\hline & $\begin{array}{l}\text { Apparent } \\
\text { Temperature }\end{array}$ & 22.1 & 12.1 & -250.2 & $\begin{array}{l}-362.7 \\
-137.7\end{array}$ & * & 32.1 & -344.7 & $\begin{array}{l}-610.3 \\
-79.2\end{array}$ & * & 33.3 & 4836.1 \\
\hline & $\begin{array}{l}\text { Percentile } \\
\text { Temp }\end{array}$ & 68th & 10th & -767.1 & $\begin{array}{l}-965.4 \\
-568.7\end{array}$ & * & 90th & -353.8 & $\begin{array}{l}-581.8 \\
-125.7\end{array}$ & * & 34.8 & 4814.3 \\
\hline & $\begin{array}{l}\text { Without } \\
\text { pollution } \\
\text { index }\end{array}$ & 18.8 & 8.8 & -310.5 & $\begin{array}{l}-419.7 \\
-201.3\end{array}$ & * & 28.7 & -377.0 & $\begin{array}{l}-613.1 \\
-140.9\end{array}$ & * & 31.9 & 5161.6 \\
\hline \multirow[t]{4}{*}{$\mathrm{SH}$} & $\begin{array}{l}\text { Original } \\
\text { (Mean } \\
\text { Temp) }\end{array}$ & 17.9 & 7.9 & -251.6 & $\begin{array}{l}-423.0 \\
-80.1\end{array}$ & * & 27.9 & -432.7 & $\begin{array}{l}-636.2 \\
-229.1\end{array}$ & * & 38.6 & 4851.0 \\
\hline & $\begin{array}{l}\text { Apparent } \\
\text { Temperature }\end{array}$ & 18.6 & 8.6 & -145.2 & $\begin{array}{l}-297.8 \\
7.4\end{array}$ & & 28.6 & -187.3 & $\begin{array}{l}-362.5 \\
-12.1\end{array}$ & * & 36.6 & 4878.3 \\
\hline & $\begin{array}{l}\text { Percentile } \\
\text { Temp }\end{array}$ & 54th & 10th & -356.9 & $\begin{array}{l}-571.7 \\
-142.0\end{array}$ & * & 90th & -514.0 & $\begin{array}{l}-744.1 \\
-283.9\end{array}$ & * & 37.5 & 4845.4 \\
\hline & $\begin{array}{l}\text { Without } \\
\text { pollution } \\
\text { index }\end{array}$ & 17.9 & 7.9 & -237.9 & $\begin{array}{l}-408.2 \\
-67.5\end{array}$ & * & 27.9 & -402.2 & $\begin{array}{l}-597.9 \\
-206.5\end{array}$ & * & 35.0 & 5193.6 \\
\hline \multirow[t]{4}{*}{ CQ } & $\begin{array}{l}\text { Original } \\
\text { (Mean } \\
\text { Temp) }\end{array}$ & 16.1 & 6.1 & -19.1 & $\begin{array}{l}-293.1 \\
254.9\end{array}$ & & 26.0 & -321.7 & $\begin{array}{l}-526.6 \\
-116.8\end{array}$ & * & 38.2 & 4931.6 \\
\hline & $\begin{array}{l}\text { Apparent } \\
\text { Temperature }\end{array}$ & 15.3 & 5.3 & 1.8 & $\begin{array}{l}-253.6 \\
257.1\end{array}$ & & 25.3 & -138.3 & $\begin{array}{l}-319.8 \\
43.2\end{array}$ & & 35.8 & 4984.7 \\
\hline & $\begin{array}{l}\text { Percentile } \\
\text { Temp }\end{array}$ & 48th & 10th & -51.3 & $\begin{array}{l}-284.2 \\
181.5\end{array}$ & & 90th & -812.0 & $\begin{array}{l}-1080.0 \\
-544.0\end{array}$ & * & 38.3 & 4949.1 \\
\hline & $\begin{array}{l}\text { Without } \\
\text { pollution } \\
\text { index }\end{array}$ & 19.3 & 9.3 & -126.1 & $\begin{array}{l}-398.6 \\
146.4\end{array}$ & & 29.3 & -501.0 & $\begin{array}{l}-808.0 \\
-194.0\end{array}$ & * & 36.4 & 5273.9 \\
\hline \multirow[t]{5}{*}{ SZ } & $\begin{array}{l}\text { Original } \\
\text { (Mean } \\
\text { Temp) }\end{array}$ & 24.2 & 14.2 & -351.7 & $\begin{array}{l}-614.8 \\
-88.6\end{array}$ & * & 30.8 & -204.8 & $\begin{array}{l}-514.5 \\
104.8\end{array}$ & & 38.9 & 4795.1 \\
\hline & $\begin{array}{l}\text { Apparent } \\
\text { Temperature }\end{array}$ & 27.0 & 17.0 & -96.0 & $\begin{array}{l}-274.8 \\
82.9\end{array}$ & & 37.0 & -126.5 & $\begin{array}{l}-367.8 \\
114.7\end{array}$ & & 36.2 & 4832.2 \\
\hline & $\begin{array}{l}\text { Percentile } \\
\text { Temp }\end{array}$ & 58th & 10th & -279.7 & $\begin{array}{l}-509.9 \\
-49.5\end{array}$ & * & 90th & -171.8 & $\begin{array}{l}-390.3 \\
46.7\end{array}$ & & 38.0 & 4794.8 \\
\hline & $\begin{array}{l}\text { Without } \\
\text { Pollution } \\
\text { index }\end{array}$ & 23.8 & 13.8 & -310.1 & $\begin{array}{l}-577.8 \\
-42.5\end{array}$ & * & 30.8 & -213.4 & $\begin{array}{l}-511.8 \\
85.2\end{array}$ & & 36.1 & 5137.4 \\
\hline & $\begin{array}{l}\text { Without } \\
\text { Typhoon }\end{array}$ & 24.2 & 14.2 & -352.6 & $\begin{array}{l}-613.6 \\
-91.6\end{array}$ & * & 30.8 & -204.6 & $\begin{array}{l}-513.2 \\
104.0\end{array}$ & & 37.9 & 4781.1 \\
\hline \multirow[t]{2}{*}{$\mathrm{HK}$} & $\begin{array}{l}\text { Original } \\
\text { (Mean } \\
\text { Temp) }\end{array}$ & $20^{\mathrm{a}}$ & 10.0 & -3.0 & $\begin{array}{l}-331.8 \\
325.8\end{array}$ & & 30.0 & -105.4 & $\begin{array}{l}-268.5 \\
57.6\end{array}$ & & 30.6 & 5365.2 \\
\hline & $\begin{array}{l}\text { Apparent } \\
\text { Temperature }\end{array}$ & $20^{a}$ & 10.0 & -9.5 & $\begin{array}{l}-273.0 \\
254.1\end{array}$ & & 30.0 & -83.7 & $\begin{array}{l}-150.4 \\
-17.1\end{array}$ & * & 30.7 & 5365.0 \\
\hline
\end{tabular}




\begin{tabular}{|c|c|c|c|c|c|c|c|c|c|}
\hline $\begin{array}{l}\text { Percentile } \\
\text { Temp }\end{array}$ & 50 th $^{a}$ & 10th & -10.4 & $\begin{array}{l}-221.3 \\
200.6\end{array}$ & 90th & -173.1 & $\begin{array}{l}-382.9 \\
36.8\end{array}$ & 30.7 & 5363.3 \\
\hline $\begin{array}{l}\text { Without } \\
\text { Pollution } \\
\text { index }\end{array}$ & 21.9 & 11.9 & -128.8 & $\begin{array}{l}-523.0 \\
265.3\end{array}$ & 31.2 & -348.0 & $\begin{array}{l}-697.8 \\
1.8\end{array}$ & 34.7 & 5373.7 \\
\hline $\begin{array}{l}\text { Without } \\
\text { Typhoon }\end{array}$ & $20^{a}$ & 10.0 & -3.7 & $\begin{array}{l}-328.9 \\
321.6\end{array}$ & 30.0 & -104.2 & $\begin{array}{l}-261.1 \\
52.7\end{array}$ & 29.9 & 5350.4 \\
\hline
\end{tabular}

Note: $\mathrm{BJ}=$ Beijing, $\mathrm{SH}=$ Shanghai, $\mathrm{CQ}=$ Chongqing, $\mathrm{SZ}$ = Shenzhen, $\mathrm{HK}=$ Hong Kong; OptT = optimal temperature; $\mathrm{Cl}=$ confidence interval; $\mathrm{df}=$ degrees of freedom; $\mathrm{AIC}=$ Akaike information criterion. The model for each city was adjusted for relative humidity\#, precipitation, windspeed, pressure\#, sunshine, AQI/AQHI, month, day of week, public holiday, extra workdays, typhoon, super typhoon, and marathon (\#some cities had these variables removed in the stepdown process). Percentile temperatures were set to $10^{\text {th }}$ and $90^{\text {th }}$ percentiles for analysis.

aWhere association was not curvilinear, the optimal temperature was pre-set to $20^{\circ} \mathrm{C}$ or $50^{\text {th }}$ percentile.

* $p \leq 0.05$ indicates significant difference.

\section{Discussion}

Inverse U-shaped associations of temperature on city-wide aggregated step counts in four of five Chinese cities (Beijing, Shanghai, Chongqing, and Shenzhen) were found, with significant decreases in high temperatures for three cities (Beijing, Shanghai, and Chongqing). Step counts peaked at optimal temperatures ranging from $16.0^{\circ} \mathrm{C}$ in Chongqing, $17.9^{\circ} \mathrm{C}$ in Shanghai, $19.3^{\circ} \mathrm{C}$ in Beijing, to $24.2^{\circ} \mathrm{C}$ in Shenzhen. In warm temperatures, average decreases of 322 to 433 steps were found for those cities at $10^{\circ} \mathrm{C}$ increase from optimal temperature, while temperatures in Shenzhen did not extend high enough to find a significant association. Among cities with a significant decrease in high temperatures, steeper decreases of physical activity were found in hot temperatures compared to cold temperatures. In Hong Kong, a non-significant association was found between temperature and step count, however, a marginally significant curvilinear association was found with optimal temperatures at $21.9^{\circ} \mathrm{C}$ when the city-specific air pollution index (AQHI) was taken out of the model, and a significant negative association was found in high apparent temperatures. Optimal percentile temperatures ranged between 48th percentile in Chongqing to 68th percentile in Beijing. Other results remained largely consistent in the sensitivity analyses.

Only a few temperature-physical activity studies have previously been conducted in China or in the Asian region. Two studies located in Japan had similarly found curvilinear associations between temperature and step counts, with step counts peaking between $17^{\circ} \mathrm{C}$ and $20.7^{\circ} \mathrm{C}(19,51)$. A study from Harbin, China, a city in the far north with a very cold climate, found a positive association during the spring months between temperature and the intensity of activity and number of active persons in the public park (26). A previous study in Beijing found no seasonal variation and hourly association between temperature and average physical activity among 40 Chinese participants of an accelerometer study (25). However, the study seemed to only consider the possibility of a linear association using general linear models. In Hong Kong, a study on Pokémon Go users found a significant negative association between temperature and daily distance travelled in the summer (24), while the negative association in our study was non-significant.

In other published multi-location studies, a trail study across the USA found increasing optimal temperatures with warmer American-centric climate regions (18). In this study, locations with similar climates had similar associations, however warmer locations did not necessarily have the greater effects in high temperatures. Chongqing and Shanghai (both climate Cfa under the Köppen-Geiger classification (52)) had similar optimal temperature peaks and clear decreased physical activity associations in warm temperatures. Warmer Shenzhen and Hong Kong (both climate Cwa) found similar optimal temperature peaks ranging in the early $20 \mathrm{~s}^{\circ} \mathrm{C}$, particularly in the Hong Kong model without air pollution. However, non-significant decreases in step counts were found with higher temperatures, as both cities had lower extreme temperatures (maximum temp: $30.8^{\circ} \mathrm{C}$ and $31.2^{\circ} \mathrm{C}$, respectively) compared to the other cities. Surprisingly, Beijing (climate Dwa) had a relatively high optimal temperature $\left(19.3^{\circ} \mathrm{C}\right)$ and the highest percentile optimal temperature at 68th percentile, despite having an overall colder climate. 
This study found that optimal temperatures for physical activity ranged between 48th to 68th percentile, with the highest percentile found in Beijing. As indicated by Beijing's climate classification Dwa, the 'a' demonstrates hot summer temperatures in an overall cold snow climate zone ' $D$ ' (52). This produces a wider temperature range than other cities, as seen in Table 2. With half of days having mean temperatures below $12^{\circ} \mathrm{C}$ in Beijing, the population may seek to take advantage of the warmer temperatures and other connected weather conditions (increased daylight hours, absence of icy surfaces etc.) to conduct more active leisure activities (53), leading to the findings of a greater increase of physical activity in warmer temperatures and higher optimal temperature than other cities. Additionally, the inter-city variations in physical activity patterns seem to demonstrate population adaptation to local climates (54) and may have also been influenced by variations in infrastructural or spatial patterns of the urban environment, such as the city density and urban sprawl (55). As mentioned in a Beijing study on travel behaviour, the built environment can significantly affect people's allocation of time and pursuit of activities (56).

In the stratified analyses, lower optimal temperatures were found among females in all cities with curvilinear relationships. This is a new finding, as previous studies that stratified by gender did not assess for a difference in optimal temperature between genders $(51,53,57,58)$. Only one study stratifying by gender found overall lower step counts among females compared to males (51), while other studies did not find clear differences in temperature-related physical activity between males and females $(53,57,58)$. Our study also found that elderly over 65 had lower optimal temperatures and larger decreases of step count in warmer temperatures compared with the adult age group. These findings are consistent with several previous studies that stratified by age and found stronger temperature effects among those over 65 , particularly over $80(51,59,60)$. These are also aligned with the physiological understanding of a lower heat tolerance among older adults due to a decreased capacity to thermoregulate $(61,62)$.

\section{Strengths and limitations}

This was the first multi-location comparative study on temperature and physical activity located in China and in Asia. This study demonstrated a decrease of daily physical activity in high temperatures using aggregated objectively measured step counts from a large, anonymized sample size. The data collection method ensured that anonymized users were located in the respective cities in order to be included in the analysis. A non-linear statistical analysis allowed for flexible associations between temperature and physical activity, as well as all other meteorological variables. The analysis comprised over a year's duration, covered all seasons, and controlled for time-related variables and holidays and special events (typhoons and marathons) where feasible.

However, this study's data collection was limited to only those who voluntarily downloaded the mobile application, and may have skewed towards the health-conscious, able-bodied (no mobility problems), younger, and more active subset of the population. This can be seen by the relatively high average daily step count of each city and the skewed age distribution compared to the general population, and suggests that this study may underestimate the temperature effect, particularly among more vulnerable populations. The accelerometer could only collect information on ambulatory activities when the phone was located with the person and was unable to account for any cycling or aquatic activities. As this study could not control for whether the anonymized users kept their phones on them, the aggregation from a large data sample could be an underestimation of actual physical activity levels. Finally, the aggregated data could not control at the individual participant level and would have included any visitors or temporary stay individuals who used the in-app function and were located in the city during any evenings of the study period.

\section{Future research directions}

Future studies should assess the temperature-physical activity relationship in more climate and geographically diverse locations of China and other regions. An increased understanding is needed on the role of urban planning and spatial patterns in affecting the relationship between temperature and physical activity. Extreme temperature events could be assessed in warmer subtropical climate locations like Shenzhen and Hong Kong, to elucidate the effect of extreme temperatures.

Furthermore, the singular effect of the super typhoon in these two cities also hints at the large impact that extreme weather events can have on population physical activity patterns. With climate change and an increased frequency of heat waves, 
typhoons, storms, and other climate-related hazards, there may be increased days where population activity is lowered by such extreme events. Studies could further examine and project the impact of physical activity in extreme weather events.

\section{Conclusions}

This study demonstrated that the public health burden of cold and hot temperatures extended to physical activity, an important health behaviour for populational well-being. An association between temperatures and physical activity was found in the major cities in China, with physical activity peaking between $16^{\circ} \mathrm{C}$ to $19.3^{\circ} \mathrm{C}$ in temperate climate cities. The impact of temperature seemed to be greater in climates with wider temperature ranges, whereas cities in subtropical climates did not have significant declines in step counts on days with high temperatures. On days with extremely hot temperatures, the mean step counts of the city population decreased as far as 800 to 1500 steps compared to the optimal temperature. With increasing temperatures from climate change, cities could possibly see a reduction in their population physical activity levels, as the temperatures shift higher than the optimal temperature for physical activity. The impact of these minor reductions in physical activity could subsequently lead to consequential health effects. Awareness of decreased physical activity in cold and heat would help formulate adaptations to the promotion of physical activity in China. Healthcare providers should be informed to provide appropriate physical activity recommendations and heat prevention measures. Recommended city-wide interventions include increased access to indoor recreational facilities and urban design measures to alleviate the heat and to support sustainable physical activity levels in the face of climate change.

\section{Declarations}

\section{Ethics approval:}

Ethics approval on the secondary data was obtained from the Survey and Behavioural Research Ethics Committee of The Chinese University of Hong Kong.

\section{Consent for publication:}

Not applicable

\section{Availability of data and materials:}

The data that support the findings of this study are available from Wechat WeRun but restrictions apply to the availability of these data, which were used under agreement for the current study, and so are not publicly available.

\section{Competing interests:}

The authors declare that they have no competing interests.

\section{Funding:}

JYH conducted the research while an intern at Tencent and was funded by the Hong Kong PhD Fellowship Scheme from the Hong Kong Research Grants Council (PF15-18545) during the same period. JYH is partially supported by the Research Impact Fund (Ref-No: R4046-18) of the Hong Kong Research Grants Council.

\section{Authors' contributions:}


JYH, WBG, PKHM and EYYC contributed to the conceptualization, design, interpretation, and writing. JYH acquired and analysed the data. All authors read and approved the final manuscript.

\section{Acknowledgements:}

The authors wish to thank the Tencent team for their data and technical support, with special thanks to Dr. Wujie Zheng and Ms. Diane Liu. The anonymized aggregated data was shared for research purposes only. The authors would also like to thank Professor Ming Luo for his data support. JYH conducted the research while an intern at Tencent and was funded by the Hong Kong PhD Fellowship Scheme from the Hong Kong Research Grants Council (PF15-18545) during the same period. JYH is partially supported by the Research Impact Fund (Ref-No: R4046-18) of the Hong Kong Research Grants Council.

\section{References}

1. Barnett AG, Hajat S, Gasparrini A, Rocklov J. Cold and heat waves in the United States. Environ Res. 2012;112:218-24.

2. Gasparrini A, Guo Y, Hashizume M, Lavigne E, Zanobetti A, Schwartz J, et al. Mortality risk attributable to high and low ambient temperature: a multicountry observational study. The Lancet. 2015;386(9991):369-75.

3. Kovats RS, Hajat S. Heat stress and public health: a critical review. Annu Rev Public Health. 2008;29:41-55.

4. Chan EYY, Goggins WB, Kim JJ, Griffiths SM. A study of intracity variation of temperature-related mortality and socioeconomic status among the Chinese population in Hong Kong. J Epidemiol Community Health. 2012;66(4):322-7.

5. Goggins WB, Chan EY, Yang C, Chong M. Associations between mortality and meteorological and pollutant variables during the cool season in two Asian cities. Environ Health. 2013;12(59).

6. Chan EYY, Goggins WB, Yue JS, Lee P. Hospital admissions as a function of temperature, other weather phenomena and pollution levels in an urban setting in China. Bull World Health Organ. 2013;91(8):576-84.

7. Chan EYY, Lam HCY, So SHW, Goggins WB, Ho JY, Liu S, et al. Association between Ambient Temperatures and Mental Disorder Hospitalizations in a Subtropical City: A Time-Series Study of Hong Kong Special Administrative Region. Int J Environ Res Public Health. 2018;15(4).

8. Ye X, Wolff R, Yu W, Vaneckova P, Pan X, Tong S. Ambient temperature and morbidity: a review of epidemiological evidence. Environ Health Perspect. 2012;120(1):19-28.

9. Chan EYY, Goggins WB, Kim JJ, Griffiths S, Ma TK. Help-seeking behavior during elevated temperature in Chinese population. J Urban Health. 2011;88(4):637-50.

10. Lee IM, Shiroma EJ, Lobelo F, Puska P, Blair SN, Katzmarzyk PT. Effect of physical inactivity on major non-communicable diseases worldwide: an analysis of burden of disease and life expectancy. The Lancet. 2012;380(9838):219-29.

11. Bull FC, Bauman AE. Physical inactivity: the "Cinderella" risk factor for noncommunicable disease prevention. J Health Commun. 2011;16 Suppl 2:13-26.

12. Durstine JL, Gordon B, Wang Z, Luo X. Chronic disease and the link to physical activity. Journal of Sport and Health Science. 2013;2(1):3-11.

13. Physical Activity Guidelines Advisory Committee. 2018 Physical Activity Guidelines Advisory Committee Scientific Report. Washington, DC: US Department of Health and Human Services; 2018.

14. Chan CB, Ryan DA. Assessing the effects of weather conditions on physical activity participation using objective measures. Int J Environ Res Public Health. 2009;6(10):2639-54.

15. Tucker P, Gilliland J. The effect of season and weather on physical activity: a systematic review. Public Health. 2007;121(12):909-22.

16. Al-Mohannadi AS, Farooq A, Burnett A, Van Der Walt M, Al-Kuwari MG. Impact of Climatic Conditions on Physical Activity: A 2-Year Cohort Study in the Arabian Gulf Region. J Phys Act Health. 2016;13(9):929-37.

17. de Montigny L, Ling R, Zacharias J. The Effects of Weather on Walking Rates in Nine Cities. Environment and Behavior. 2011;44(6):821-40. 
18. Ermagun A, Lindsey G, Loh TH. Urban trails and demand response to weather variations. Transportation Research Part D: Transport and Environment. 2018;63:404-20.

19. Togo F, Watanabe E, Park H, Shephard RJ, Aoyagi Y. Meteorology and the physical activity of the elderly: the Nakanojo Study. Int J Biometeorol. 2005;50(2):83-9.

20. National Bureau of Statistics of China. Total Population (year-end) Beijing: National Bureau of Statistics of China; 2019 [Available from: https://data.stats.gov.cn/english/easyquery.htm?cn=C01.

21. Yang J, Siri JG, Remais JV, Cheng Q, Zhang H, Chan KKY, et al. The Tsinghua-Lancet Commission on Healthy Cities in China: unlocking the power of cities for a healthy China. The Lancet. 2018;391(10135):2140-84.

22. Zang J, Ng SW. Age, period and cohort effects on adult physical activity levels from 1991 to 2011 in China. Int J Behav Nutr Phys Act. 2016;13:40.

23. National Development and Reform Commission P. China's National Climate Change Programme. China: National Development and Reform Commission; 2007.

24. Ma BD, Ng SL, Schwanen T, Zacharias J, Zhou M, Kawachi I, et al. Pokemon GO and Physical Activity in Asia: Multilevel Study. J Med Internet Res. 2018;20(6):e217.

25. Wang G, Li B, Zhang X, Niu C, Li J, Li L, et al. No seasonal variation in physical activity of Han Chinese living in Beijing. Int J Behav Nutr Phys Act. 2017;14(1):48.

26. Zhao X, Bian Q, Zhao D, Zhang B. Activity Intensity and Micro-climate Regulation of Vegetation Community of Cold Region Parks in Spring (Chinese). 峸区. 2018(2):42-8.

27. Hallal PC, Andersen LB, Bull FC, Guthold R, Haskell W, Ekelund U. Global physical activity levels: surveillance progress, pitfalls, and prospects. The Lancet. 2012;380(9838):247-57.

28. Alahmari AD, Mackay AJ, Patel AR, Kowlessar BS, Singh R, Brill SE, et al. Influence of weather and atmospheric pollution on physical activity in patients with COPD. Respir Res. 2015;16:71.

29. Badland HM, Christian H, Giles-Corti B, Knuiman M. Seasonality in physical activity: should this be a concern in all settings? Health Place. 2011;17(5):1084-9.

30. Chan CB, Ryan DA, Tudor-Locke C. Relationship between objective measures of physical activity and weather: a longitudinal study. Int J Behav Nutr Phys Act. 2006;3:21.

31. Giannouli E, Fillekes MP, Mellone S, Weibel R, Bock O, Zijlstra W. Predictors of real-life mobility in community-dwelling older adults: an exploration based on a comprehensive framework for analyzing mobility. Eur Rev Aging Phys Act. 2019;16:19.

32. Ogawa S, Seko T, Ito T, Mori M. Differences in physical activity between seasons with and without snowfall among elderly individuals residing in areas that receive snowfall. The Journal of Physical Therapy Science. 2019;31:12-6.

33. Hekler EB, Buman MP, Grieco L, Rosenberger M, Winter SJ, Haskell W, et al. Validation of Physical Activity Tracking via Android Smartphones Compared to ActiGraph Accelerometer: Laboratory-Based and Free-Living Validation Studies. JMIR Mhealth Uhealth. 2015;3(2):e36.

34. Presset B, Laurenczy B, Malatesta D, Barral J. Accuracy of a smartphone pedometer application according to different speeds and mobile phone locations in a laboratory context. J Exerc Sci Fit. 2018;16(2):43-8.

35. Bort-Roig J, Gilson ND, Puig-Ribera A, Contreras RS, Trost SG. Measuring and influencing physical activity with smartphone technology: a systematic review. Sports Med. 2014;44(5):671-86.

36. Aral S, Nicolaides C. Exercise contagion in a global social network. Nat Commun. 2017;8:14753.

37. Vanky AP, Verma SK, Courtney TK, Santi P, Ratti C. Effect of weather on pedestrian trip count and duration: City-scale evaluations using mobile phone application data. Prev Med Rep. 2017;8:30-7.

38. Ho JY, Zijlema WL, Triguero-Mas M, Donaire-Gonzalez D, Valentin A, Ballester J, et al. Does surrounding greenness moderate the relationship between apparent temperature and physical activity? Findings from the PHENOTYPE project. Environ Res. 2021;197:110992. 
39. Amagasa S, Kamada M, Sasai H, Fukushima N, Kikuchi H, Lee IM, et al. How Well iPhones Measure Steps in Free-Living Conditions: Cross-Sectional Validation Study. JMIR Mhealth Uhealth. 2019;7(1):e10418.

40. Ballester J, Robine JM, Herrmann FR, Rodo X. Long-term projections and acclimatization scenarios of temperature-related mortality in Europe. Nat Commun. 2011;2:358.

41. Sensirion. Application Note Dew-point calculation. In: Sensirion, editor. Switzerland2006. p. 1-3.

42. China Meteorological Administration. Member Report of China. Chiang Mai, Thailand: ESCAP/WMO Typhoon Committee, 13th Integrated Workshop; 2018.

43. Hong Kong Observatory. Tropical Cyclone Warning Signals Hong Kong: Hong Kong Observatory; 2018 [Available from: https://www.hko.gov.hk/en/wxinfo/climat/warndb/warndb1.shtml.

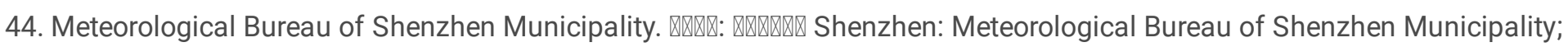
2018 [Available from: http://weather.sz.gov.cn/qixiangfuwu/yujingfuwu/lishiyujingchaxun/.

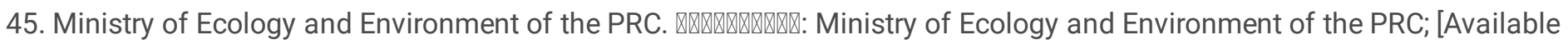
from: http://www.mee.gov.cn/.

46. Environmental Protection Department. About AQHI Hong Kong SAR: Environmental Protection Department HKSAR; [Available from: https://www.aqhi.gov.hk/en/what-is-aqhi/about-aqhi.html.

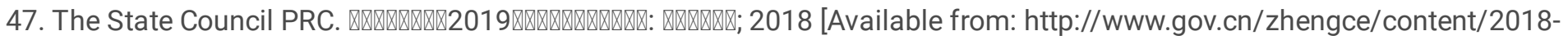
12/06/content_5346276.htm.

48. Major Sports Events Committee. "M" Mark Events Calendar Hong Kong2018 [Available from: http://www.mevents.org.hk/en/calendar_2018.php.

49. R Core Team. R: A language and environment for statistical computing. Vienna, Austria: R Foundation for Statistical Computing; 2018.

50. Wood S. Generalized Additive Models: An Introduction with R, 2nd edition: Chapman and Hall/CRC; 2017.

51. Hino K, Lee JS, Asami Y. Associations between seasonal meteorological conditions and the daily step count of adults in Yokohama, Japan: Results of year-round pedometer measurements in a large population. Prev Med Rep. 2017;8:15-7.

52. Kottek M, Grieser J, Beck C, Rudolf B, Rubel F. World Map of the Köppen-Geiger climate classification updated. Meteorologische Zeitschrift. 2006;15(3):259-63.

53. Aspvik NP, Viken H, Ingebrigtsen JE, Zisko N, Mehus I, Wisloff U, et al. Do weather changes influence physical activity level among older adults? - The Generation 100 study. PLoS One. 2018;13(7):e0199463.

54. Ma W, Wang L, Lin H, Liu T, Zhang Y, Rutherford S, et al. The temperature-mortality relationship in China: An analysis from 66 Chinese communities. Environ Res. 2015;137:72-7.

55. LV J, Yang BD, Yang YJ, Zhang ZH, Chen F, Liu GJ. Spatial Patterns of China's Major Cities and Their Evolution Mechanisms during the Past Decades of Reform and Opening Up. Procedia Engineering. 2017;198:915-25.

56. Wang D, Chai Y, Li F. Built environment diversities and activity-travel behaviour variations in Beijing, China. Journal of Transport Geography. 2011;19(6):1173-86.

57. Bosdriesz JR, Witvliet MI, Visscher TL, Kunst AE. The influence of the macro-environment on physical activity: a multilevel analysis of 38 countries worldwide. Int J Behav Nutr Phys Act. 2012;9(110).

58. Klenk J, Buchele G, Rapp K, Franke S, Peter R, Acti FESG. Walking on sunshine: effect of weather conditions on physical activity in older people. J Epidemiol Community Health. 2012;66(5):474-6.

59. Obradovich N, Fowler JH. Climate change may alter human physical activity patterns. Nature Human Behaviour. 2017;1(5).

60. Witham MD, Donnan PT, Vadiveloo T, Sniehotta FF, Crombie IK, Feng Z, et al. Association of day length and weather conditions with physical activity levels in older community dwelling people. PLoS One. 2014;9(1):e85331.

61. Balmain BN, Sabapathy S, Louis M, Morris NR. Aging and Thermoregulatory Control: The Clinical Implications of Exercising under Heat Stress in Older Individuals. Biomed Res Int. 2018;2018:8306154. 
62. Kenny GP, Yardley J, Brown C, Sigal RJ, Jay O. Heat stress in older individuals and patients with common chronic diseases. CMAJ. 2010;182(10):1053-60.

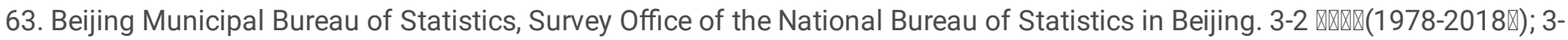

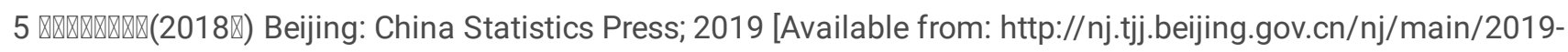
tjnj/zk/indexce.htm.

64. Census and Statistics Department. Table 002 : Population by Age Group and Sex Hong Kong SAR: Census and Statistics Department, The Government of HKSAR; 2019 [updated Aug 13, 2020. Available from: https://www.censtatd.gov.hk/hkstat/sub/sp150.jsp?tableID=002\&ID=0\&productType=8.

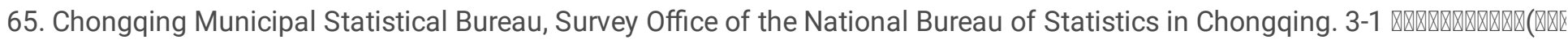

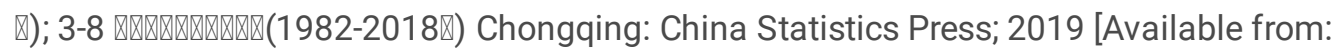
http://tjj.cq.gov.cn/zwgk_233/tjnj/2019/zk/indexch.htm.

66. Shanghai Municipal Statistical Bureau, Survey Office of the National Bureau of Statistics in Shanghai. 2.1 Total Households, Population, Density of Registered Population and Life Expectancy (1978ه2018); 2.6 Age Structure of Registered Population in Districts (2018) Shanghai: China Statistics Press; 2019 [Available from: http://tjj.sh.gov.cn/tjnj/zgsh/tjnj2019en.html.

67. Shenzhen Municipal Statistics Bureau. 2018

\section{Figures}



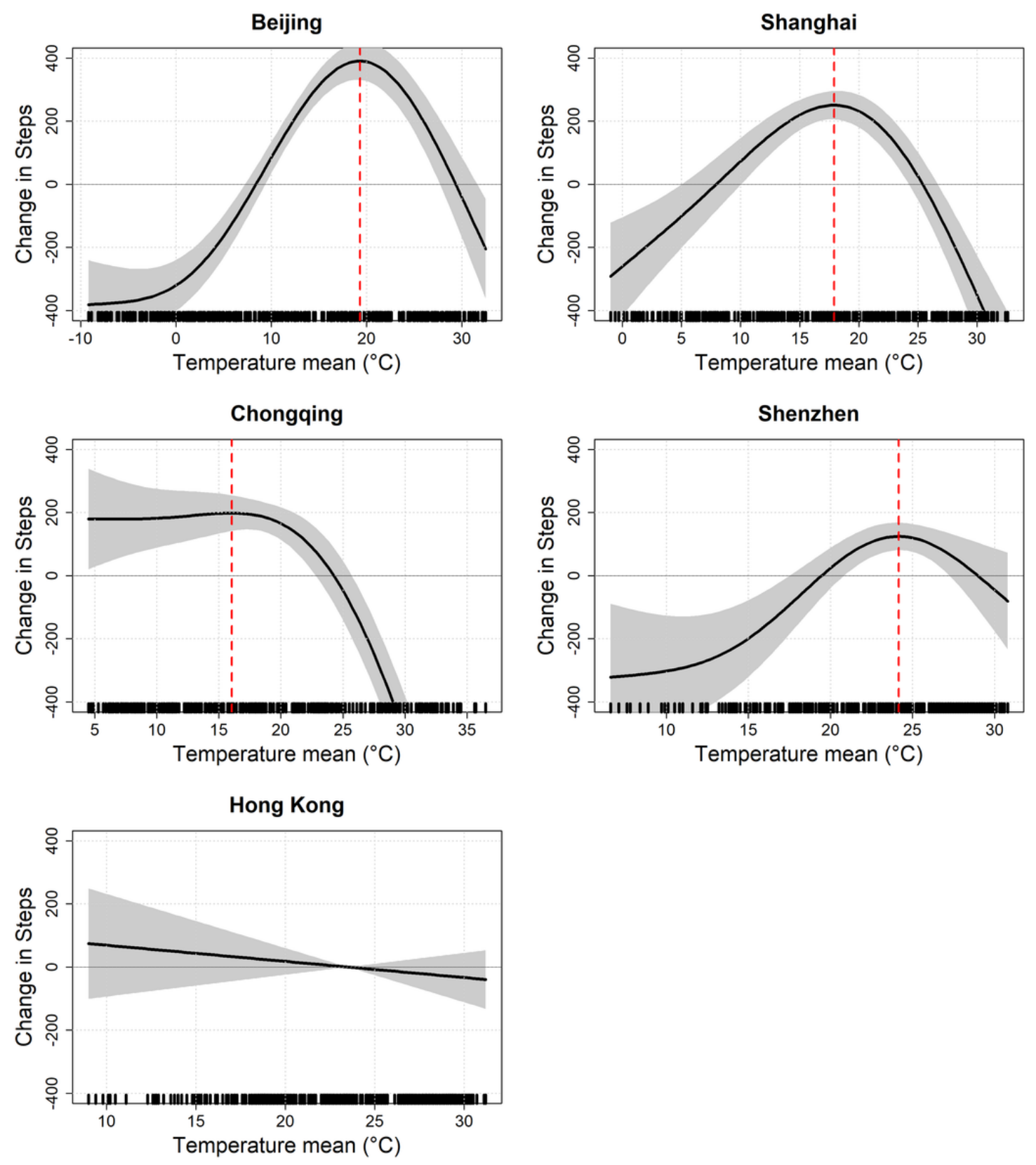

Figure 1

Relationships between temperature and daily step count in five Chinese cities Note: The model for each city was adjusted for relative humidity\#, precipitation, windspeed, pressure\#, sunshine, AQI/AQHI, month, day of week, public holiday, extra workdays, typhoon, super typhoon, and marathon (\#some cities had these variables removed in the stepdown process). Black markings along the $x$-axis indicate the actual existing temperature data of each city; Vertical red dotted lines indicate the identified optimal temperature; Grey shading indicates the $95 \%$ confidence interval.

\section{Supplementary Files}

This is a list of supplementary files associated with this preprint. Click to download.

- Supplementalmaterial.docx 